American Journal of Applied Sciences 6 (12): 2085-2092, 2009

ISSN 1546-9239

(C) 2009 Science Publications

\title{
Cryptic Mantle Metasomatism: Evidences from Spinel Lherzolite Xenoliths/Al-Harida Volcano in Harrat Al-Shaam, Jordan
}

\author{
Ahmad Al-Malabeh \\ Department of Earth and Environmental Sciences, \\ Hashemite University, P.O. Box 150459, Zarqa 13115, Jordan
}

\begin{abstract}
Problem statement: Al-Harida volcano is located in the Jordanian parts of the Harrat AlShaam plateau and contains considerable amounts of mantle xenoliths within its pyroclastic successions. Approach: These xenoliths are reported for the first time for this area. Mineralogical investigations show that they are composed of olivine, orthopyroxene, clinopyroxene, spinel and phlogopite. Results: The xenoliths range in size from $5-30 \mathrm{~cm}$ with an average of $10 \mathrm{~cm}$. They are classified as Type I and belong to the Cr-diopside group and are characterized by high contents of $\mathrm{MgO}, \mathrm{Cr}$ and $\mathrm{Ni}$. The occurrence of hydrous mineral phases and the enrichment of incompatible elements such as $\mathrm{Sr}, \mathrm{Rb}$ and $\mathrm{Ba}$ indicate a considerable mantle metasomatism. Conclusion/Recommendations: Thermobarometry of the studied xenoliths indicates a temperature ranging from $960-1040^{\circ} \mathrm{C}$ and pressure ranging from $11-13 \mathrm{Kbar}$ which corresponds to a depth of origin of about $43 \mathrm{~km}$.
\end{abstract}

Key words: Mantle metasomatism, xenoliths, spinel lherzolite, Harrat Al-Shaam, Al-Harida, Jordan

\section{INTRODUCTION}

The term metasomatism usually refers to a solidstate transformation without or only marginal melting ${ }^{[1]}$. Metasomatic xenoliths are mostly found in host magmas of mantle origin that are enriched in incompatible elements ${ }^{[2]}$ and other magmas like highly potassic mafic volcanic ${ }^{[3]}$; basanites and alkali olivine basalts $^{[4]}$. In the last three decades, mantle metasomatism has been increasingly recognized as an important process $^{[5-7]}$. However, metasomatism has been described by ${ }^{[8]}$ as the change in rock chemistry caused by the passage of hydrothermal fluids. Mantle metasomatism was at the center of the discussion in the First International Kimberlite Conference held in Capetown in $1973^{[9]}$. Three main types of metasomatism are discerned ${ }^{[10]}$ : Modal metasomatism, enrichment in major and trace elements in the absence of modal metasomatism and isolated trace element enrichment.

Experimental constrains of solubility of major and trace elements in the mantle metasomatic fluids were established by ${ }^{[11]}$. The system C-O-H-S is proposed to exist the others in the mantle volatile-bearing minerals, dissolved in silicate- or carbonate-rich melts. Fluid inclusions in mantle-derived minerals are typically found to be $\mathrm{CO}_{2}{ }^{[12,13]}$. However, $\mathrm{CO}_{2}-\mathrm{CO}$ inclusions have also been reported by Bergman and ${ }^{[14]}$. At the pressure of the upper mantle, a metasomatic fluid can consist of a carbonate-rich melt; of a silicate melt, or of a low density, volatile-rich fluid ${ }^{[9]}$.

Spinel lherzolite is considered to form the major part of the upper mantle ${ }^{[15,16]}$ occurring at depths of 40$60 \mathrm{~km}^{[17,18]}$. The existence of such xenoliths offers a direct insight into the lithosphere and the asthenosphere. Moreover, xenoliths helps in reconstructing the petrogenesis of the magma and its thermobarometeric conditions. They are relevant to the understanding of the process that gives rise to the magma and the nature of the mantle ${ }^{[19]}$. Textures of xenoliths provide the crystallization or deformation histories of these rocks within the mantle ${ }^{[20]}$.

The Tertiary-Quaternary basaltic Harrats of the Arabian plate (Fig. 1) contain several xenolith assemblages as far south as $\mathrm{Yemen}^{[21,22]}$. The Harrat AlShaam (or Ash shaam) covers an area of $45000 \mathrm{~km}^{2}$ and is the most northwestern basalt plateau of the Arabian plate. This plateau extends from Syria to Saudi Arabia through Jordan. It is considered to be one of the largest alkali olivine basalt plateaus globally. The Harrat contains a large diversity of xenolith assemblages in different localities ${ }^{[23-28]}$.

In this research, spinel lherzolite xenoliths from the Jabal Al-Harida volcano in the NE of the plateau were investigated for their chemical characteristics. The present research reports also the discovery of new xenolith occurrences in the Jordanian part of Harrat AlShaam. 
Am. J. Applied Sci., 6 (12): 2085-2092, 2009

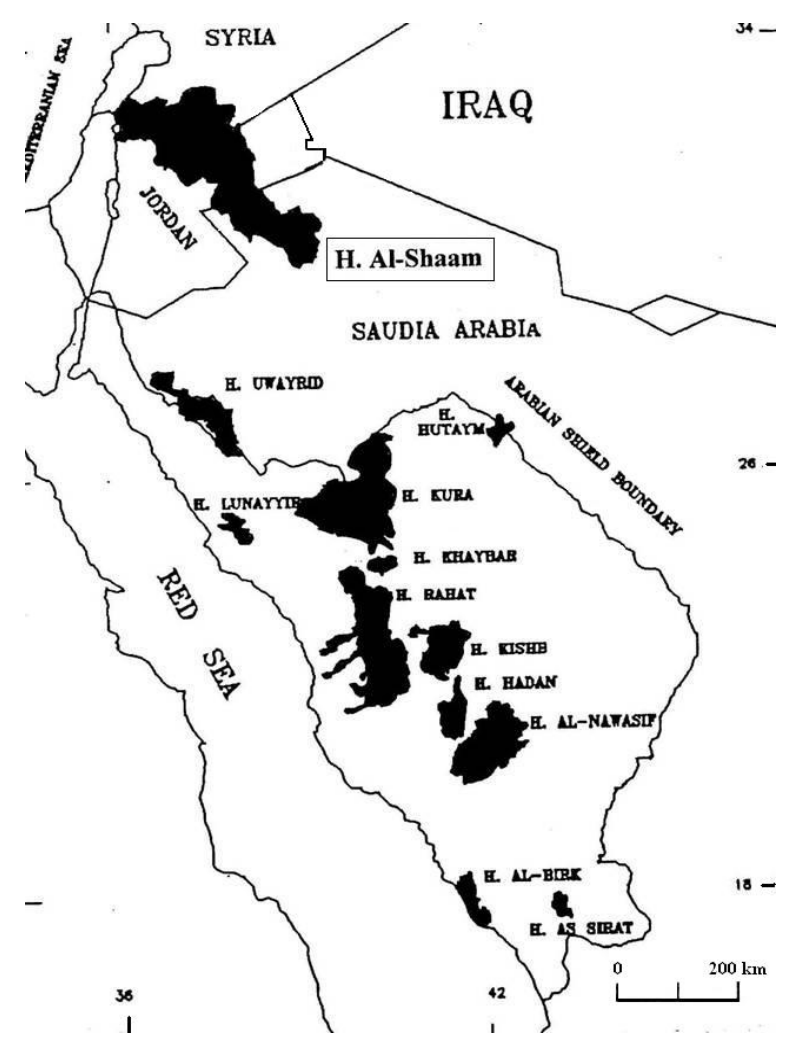

Fig. 1: Map of the Arabian plate and its basaltic Harrats (modified after Al-Malabeh ${ }^{[29]}$ )

Geologic setting: The Jordanian part of the Harra AlShaam plateau is geomorphologically known als as the Jordanian Harrat or Harrat El-Jabban ${ }^{[29,30]}$. The former name will be used in this study. It covers $11400 \mathrm{~km}^{2}$, i.e., one tenth of Jordan area (Fig. 1). The Jordanian Harrat has about 80 volcanic cones with more than 200 eruptive centers that are aligned mostly in NNW-SSE or NW-SE directions. The volcanoes cluster in three volcanic fields, those of Remah, Ashqaf and Al-Dhirwa (Fig. 2), which are located in the western, eastern and southern parts of the Harrat, respectively ${ }^{[29,31]}$.

The Ashqaf volcanic field lies in the eastern part of the Harrat (Fig. 2). It begins in the west with the Qitar Al-Abed volcanic chains and the Suwaied Volcano and ends with the Al-Harida Volcano in the east. More than 15 volcanoes are counted in this field, including more than 35 volcanic centers distributed over ca. $70 \mathrm{~km}^{2[32]}$. The distances between the volcanic centers exceed mostly $2-5 \mathrm{~km}$.

The Jabal Al-Harida Volcano is located about $40 \mathrm{~km}$ East of Al-Safawi about $15 \mathrm{~km}$ south of the Mafraq-Baghdad road at 32 11 ' $32^{\prime \prime} \mathrm{N}$ and $37^{\circ} 40^{\prime} 65^{\prime \prime} \mathrm{E}$. The volcano has a height of $70 \mathrm{~m}$ and covers an area of about $3 \mathrm{~km}^{2}$. The volcano shows an elliptical overall shape with a NW-SE striking long axis.

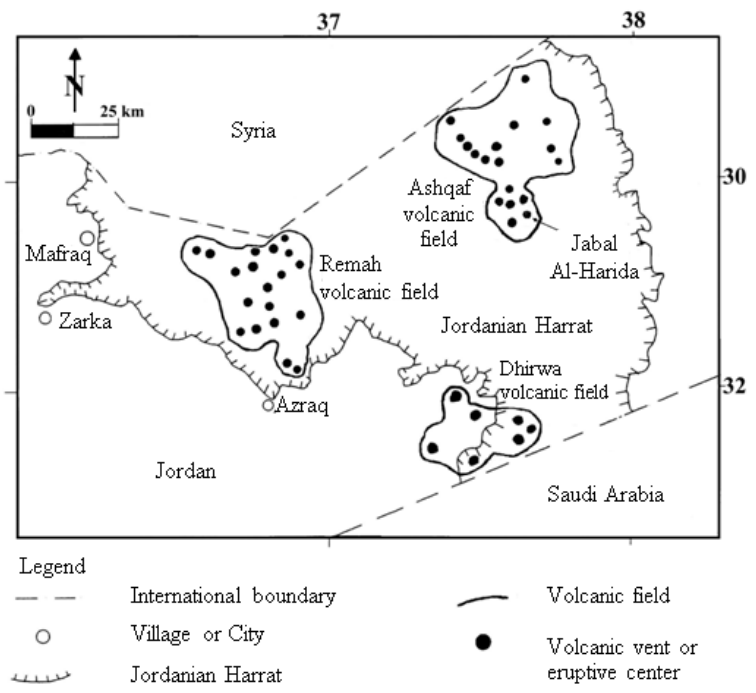

Fig. 2: Location map of Jabal Al-Harida Volcano. Data of volcanic fields are modified after AlMalabeh $^{[29,31]}$

\section{MATERIALS AND METHODS}

Analytical methods: Geochemical investigation was carried out on selected xenoliths and scoria samples. Whole rock samples were analyzed for major oxides of $\mathrm{Si}, \mathrm{Ti}, \mathrm{Al}, \mathrm{Fe}, \mathrm{Mg}, \mathrm{Mn}, \mathrm{Ca}, \mathrm{Na}, \mathrm{K}$ and $\mathrm{P}$ as well as selected trace elements using X-Ray Fluorescence (XRF) in the Department of Mineralogy, Würzburg University, Germany. Measurements were calibrated against international standards (e.g., GR1, EF1 and HW2). Loss On Ignition (LOI) was determined by weight loss after drying at $1000^{\circ} \mathrm{C}$.

Selected samples were also analyzed using an ARL-GMX electron microprobe. The analytical conditions were $1 \times 10^{-8} \mathrm{~mA}, 25-50 \mathrm{nA}$ specimen current potential, $10 \mathrm{sec}$ integration time and $20 \mathrm{kV}$ acceleration potential, the SPI mineral standards were used for the calibration process. An integration time of $10 \mathrm{sec}$ and an On-line-Data reduction was done on a computer using the Bence Albee matrix at the University of Tübingen, Germany. At least three determinations were averaged for each quoted analysis.

\section{RESULTS}

Volcanology: The Jabal Al-Harida Volcano consists of scoria-fall pyroclastic rocks that are arranged in beds and form two distinct horizons. The xenoliths were mainly collected from the upper horizon. It is xenolithrich, particularly in spinel lherzolites. These xenoliths intercalate with the pyroclastic rocks and occur as cored bombs. 
The xenoliths range in size from $2-10 \mathrm{~cm}$ with an average diameter of $5 \mathrm{~cm}$. The xenoliths are mostly light to dark green in color and spherical in shape. Some of them exhibit red to orange color.

These pyroclastic deposits show a high degree of fragmentation and are dominated by lapilli-sized ejecta. The lower horizon is composed of material mainly $<2.5 \mathrm{~cm}$ in size, which can be classified as cinder. The upper horizon is composed of two members. The lower member is composed of agglutinated pyroclastics of angular to sub-angular blocks and spherical, oval and elliptical bombs. The clasts are gray to violet in color and range in size from $10 \mathrm{~cm}$ up to $1 \mathrm{~m}$ in diameter with $30 \mathrm{~cm}$ on average. Bombs and blocks are sintered together to form agglomerates. The upper member of this horizon is gray and brown in color and $15 \mathrm{~m}$ thick and characterized by planar stratification, It consists mainly of lapilli-sized pyroclastics intercalated with blocks and bombs. This is the horizon where most of spinel lherzolites were collected.

Overall the Jabal Al-Harida Volcano can be classified as a blocky-lapilli scoria cone. The volcano appears to have resulted from multiple, explosive eruptions, separated by quite periods. The low degree of fragmentation, the basaltic affinity and the small dispersal area as well as the oxidation state of the ejecta suggest that the eruptions were Strombolian driven by magmatic degassing rather than by phreatomagmatic forces $^{[33]}$.

Petrography and mineral chemistry: The ultramafic xenoliths of Jabal Al-Harida are peridotites dominated by spinel lherzolite. The lherzolites are composed of olivine, orthopyroxene, clinopyroxene, spinel, magnetite and phlogopite. They have a protogranular texture similar to those defined by ${ }^{[34]}$. The samples are classified as Type I following the classification of ${ }^{[35]}$, while the geochemical composition classifies them as Cr-diopside peridotite following the classification of ${ }^{[36]}$.

Olivine: Olivine is the main mineral phases and forms about 25-35 vol\%. It occurs as subhedral to anhedral, medium to coarse-grained (up to $7 \mathrm{~mm}$ ) crystals. Some olivines show wavy extinction, which indicates that they were strained. Metamorphic triple junctions are also recorded in olivine denoting annealing recrystallization. Another distinguishing feature of olivine is the presence of deformation lamellae. Preferred orientation is occasionally recorded in some samples. Iddingtization of olivine is prevalent. Chemical analyses (Table 1) show that they are $\mathrm{Mg}$ rich olivines and show limited normal zoning, ranging from Fo 87 to Fo 90 (i.e., forsterite-chrysolite composition). The $\mathrm{NiO}$ content is varying between 0.23 and $0.34 \mathrm{wt} \%$, which is within the range of olivine peridotite reported by ${ }^{[37]}$ and close to the value of about 0.4 reported by ${ }^{[38]}$ for olivine of primary magmas. The chemical composition is that of the olivine of spinel lherzolite reported from Saudi Arabia given by ${ }^{[22]}$ and from Jordan by ${ }^{[39]}$.

Enstatite: Enstatite is the second most abundant mineral phase and forms up to $15 \%$ of the xenoliths. The crystals are subhedral to anhedral and coarsegrained (up to $3 \mathrm{~mm}$ ). Preferred orientation of olivine and enstatite is recorded. Furthermore, kinkband structure, deformation lamellae and exsolution lamellae of clinopyroxene are observed in the same crystals. The chemical analysis (Table 2) shows that the enstatites have the following composition Fe: 7.76-8.68; Ca 0.761.04; Mg: 90.01-91.20. They are close to enstatite composition given by ${ }^{[40]}$.

Diopside: Dopside crystals are subhedral in shape and the grain size varies from 3-6 $\mathrm{mm}$. They compose up to $12 \%$ of the volume. Chemical analysis shows that the composition of the clino-pyroxene is similar to diopside according to the classification of ${ }^{[40]}$. Diopsideendmember composition is: $\mathrm{Fe}$ : 4.11-5.50; Ca: 42.5750.96; Mg: 44.17-52.03 (Table 3). They are characterized by a high $\mathrm{Al}_{2} \mathrm{O}_{3}$ content $(1.73-2.95 \mathrm{wt} \%$ and a low $\mathrm{TiO}_{2}$ content ranging from $0.09-0.33 \mathrm{wt} \%$. The $\mathrm{Cr}_{2} \mathrm{O}_{3}$ content ranges from 1.09-2.47 wt \%. They resemble the composition of chromium-diopside ${ }^{[41]}$. Similar geochemical trends are reported by ${ }^{[42]}$ for spinel lherzolite in Jordan from the volcano Jabal AritainSouth.

Table 1: Electron microprobe analysis of olivine

\begin{tabular}{|c|c|c|c|c|c|}
\hline & $\mathrm{Hr} 1$ & $\mathrm{Hr} 1$ & $\mathrm{Hr} 4$ & $\mathrm{Hr} 4$ & \\
\hline $\mathrm{SiO}_{2}$ & 40.41 & 41.14 & 42.40 & 39.47 & 39.69 \\
\hline $\mathrm{TiO}_{2}$ & 0.03 & 0.01 & 0.04 & 0.04 & 0.02 \\
\hline $\mathrm{FeO}$ & 10.05 & 9.10 & 8.80 & 12.00 & 9.61 \\
\hline $\mathrm{MnO}$ & 0.08 & 0.05 & 0.10 & 0.11 & 0.08 \\
\hline $\mathrm{MgO}$ & 49.44 & 51.08 & 50.01 & 47.61 & 50.34 \\
\hline $\mathrm{CaO}$ & 0.04 & 0.00 & 0.01 & 0.00 & 0.00 \\
\hline $\mathrm{NiO}$ & 0.23 & 0.25 & 0.24 & 0.23 & 0.34 \\
\hline Sum & 100.11 & 101.40 & 101.37 & 99.34 & 100.08 \\
\hline \multicolumn{6}{|c|}{ Number of ions on the basis of 6 oxygen } \\
\hline $\mathrm{Si}$ & 1.486 & 1.486 & 1.525 & 1.478 & 0.975 \\
\hline $\mathrm{Ti}$ & 0.001 & 0.001 & 0.001 & 0.001 & 0.001 \\
\hline $\mathrm{Fe}$ & 0.309 & 0.275 & 0.265 & 0.378 & 0.198 \\
\hline $\mathrm{Mn}$ & 0.002 & 0.002 & 0.003 & 0.004 & 0.002 \\
\hline $\mathrm{Mg}$ & 2.710 & 2.750 & 2.650 & 2.658 & 1.843 \\
\hline $\mathrm{Ca}$ & 0.002 & 0.001 & 0.001 & 0.000 & 0.000 \\
\hline $\mathrm{Ni}$ & 0.004 & 0.005 & 0.004 & 0.004 & 0.007 \\
\hline \multicolumn{6}{|c|}{ End members } \\
\hline Fo & 89.760 & 90.090 & 90.090 & 87.54 & 90.300 \\
\hline $\mathrm{Fa}$ & 10.240 & 9.090 & 9.090 & 12.45 & 9.700 \\
\hline
\end{tabular}


Am. J. Applied Sci., 6 (12): 2085-2092, 2009

Table 2: Electron microprobe analysis of enstatite

\begin{tabular}{|c|c|c|c|c|c|}
\hline & $\mathrm{Hr} 1$ & $\mathrm{Hr} 1$ & $\mathrm{Hr} 4$ & $\mathrm{Hr} 4$ & $\mathrm{Hr} 5$ \\
\hline $\mathrm{SiO}_{2}$ & 56.63 & 56.36 & 57.36 & 57.08 & 56.61 \\
\hline $\mathrm{TiO}_{2}$ & 0.06 & 0.11 & 0.06 & 0.00 & 0.01 \\
\hline $\mathrm{Al}_{2} \mathrm{O}_{3}$ & 1.58 & 1.73 & 1.07 & 1.01 & 2.00 \\
\hline $\mathrm{Cr}_{2} \mathrm{O}_{3}$ & 0.38 & 0.48 & 0.35 & 0.46 & 0.49 \\
\hline $\mathrm{FeO}$ & 5.69 & 5.20 & 5.45 & 5.59 & 5.45 \\
\hline $\mathrm{MnO}$ & 0.08 & 0.11 & 0.12 & 0.10 & 0.09 \\
\hline $\mathrm{MgO}$ & 34.20 & 34.19 & 34.11 & 35.33 & 34.56 \\
\hline $\mathrm{CaO}$ & 0.49 & 0.52 & 0.43 & 0.46 & 0.49 \\
\hline $\mathrm{Na}_{2} \mathrm{O}$ & 0.29 & 0.06 & 0.10 & 0.11 & 0.04 \\
\hline Sum & 99.52 & 99.29 & 99.08 & 100.13 & 99.74 \\
\hline \multicolumn{6}{|c|}{ Number of ions on the basis of 6 oxygen } \\
\hline $\mathrm{Si}$ & 1.961 & 1.966 & 1.987 & 1.963 & 1.952 \\
\hline $\mathrm{Ti}$ & 0.002 & 0.003 & 0.002 & 0.000 & 0.000 \\
\hline $\mathrm{Al}$ & 0.065 & 0.071 & 0.044 & 0.041 & 0.082 \\
\hline $\mathrm{Cr}$ & 0.101 & 0.013 & 0.010 & 0.013 & 0.013 \\
\hline $\mathrm{Fe}$ & 0.169 & 0.150 & 0.158 & 0.161 & 0.157 \\
\hline $\mathrm{Mn}$ & 0.003 & 0.003 & 0.004 & 0.003 & 0.003 \\
\hline $\mathrm{Mg}$ & 1.765 & 1.762 & 1.761 & 1.811 & 1.776 \\
\hline $\mathrm{Ca}$ & 0.018 & 0.020 & 0.016 & 0.015 & 0.018 \\
\hline $\mathrm{Na}$ & 0.020 & 0.004 & 0.007 & 0.007 & 0.003 \\
\hline \multicolumn{6}{|c|}{ End members } \\
\hline $\mathrm{Mg}$ & 90.420 & 91.200 & 91.010 & 91.140 & 91.030 \\
\hline $\mathrm{Fe}$ & 8.680 & 7.760 & 8.170 & 8.100 & 8.050 \\
\hline $\mathrm{Ca}$ & 0.920 & 1.040 & 0.830 & 0.760 & 0.920 \\
\hline
\end{tabular}

Table 3: Electron microprobe analysis of diopside

\begin{tabular}{lccrrr}
\hline & $\mathrm{Hr} 1$ & $\mathrm{Hr} 1$ & \multicolumn{1}{c}{$\mathrm{Hr} 4$} & \multicolumn{1}{c}{$\mathrm{Hr} 4$} & \multicolumn{1}{c}{$\mathrm{Hr} 5$} \\
\hline $\mathrm{SiO}_{2}$ & 54.68 & 54.18 & 52.53 & 51.85 & 52.61 \\
$\mathrm{TiO}_{2}$ & 0.09 & 0.10 & 0.07 & 0.11 & 0.33 \\
$\mathrm{Al}_{2} \mathrm{O}_{3}$ & 2.95 & 2.94 & 1.73 & 2.93 & 2.22 \\
$\mathrm{Cr}_{2} \mathrm{O}_{3}$ & 1.41 & 1.44 & 2.47 & 1.45 & 1.09 \\
$\mathrm{FeO}$ & 2.76 & 3.05 & 2.54 & 2.85 & 2.50 \\
$\mathrm{MnO}$ & 0.04 & 0.05 & 0.09 & 0.07 & 0.05 \\
$\mathrm{MgO}$ & 16.27 & 16.24 & 17.43 & 16.45 & 16.51 \\
$\mathrm{CaO}$ & 19.62 & 18.53 & 20.87 & 21.82 & 22.38 \\
$\mathrm{Na} 2 \mathrm{O}$ & 1.71 & 1.74 & 0.93 & 0.90 & 0.56 \\
$\mathrm{Sum}$ & 99.56 & 98.31 & 98.68 & 98.00 & 99.33 \\
$\mathbf{N u m b e r}$ of ions on the basis of & 6 oxygen & & \\
$\mathrm{Si}$ & 1.980 & 1.985 & 0.092 & 1.930 & 1.945 \\
$\mathrm{Ti}$ & 0.003 & 0.003 & 0.076 & 0.003 & 0.009 \\
$\mathrm{Al}$ & 0.126 & 0.127 & 0.072 & 0.129 & 0.097 \\
$\mathrm{Cr}$ & 0.040 & 0.042 & 0.079 & 0.031 & 0.032 \\
$\mathrm{Fe}$ & 0.084 & 0.094 & 0.073 & 0.089 & 0.077 \\
$\mathrm{Mn}$ & 0.001 & 0.002 & 0.958 & 0.002 & 0.002 \\
$\mathrm{Mg}$ & 0.878 & 0.887 & 0.825 & 0.913 & 0.910 \\
$\mathrm{Ca}$ & 0.761 & 0.727 & 0.867 & 0.870 & 0.887 \\
$\mathrm{Na}$ & 0.120 & 0.124 & 0.092 & 0.043 & 0.041 \\
End members & & & & \\
$\mathrm{Mg}$ & 44.170 & 52.030 & 46.660 & 48.770 & 48.580 \\
$\mathrm{Fe}$ & 4.880 & 5.500 & $4,20.000$ & 4.750 & 4.110 \\
$\mathrm{Ca}$ & 50.960 & 42.570 & 46.470 & 46.470 & 47.330 \\
\hline
\end{tabular}

Spinel: Spinel is ubiquitous in all the samples collected. The crystals are anhehdral in shape and occur interstitially between the olivine and enstatite crystals, occupying from 3-7 vol.\%. Crystals are green in color and vary in grain size from $0.3-5 \mathrm{~mm}$. Some crystals show a marked wavy extinction due to strain. Glomeroporphyritic spinel crystals as many as three to five crystals are occasionally observed. The spinels (Table 4) are aluminum-rich. The $\mathrm{Al}_{2} \mathrm{O}_{3}$ ranges from
Table 4: Electron microprobe analysis of spinel

\begin{tabular}{lrrrr}
\hline & \multicolumn{1}{c}{$\mathrm{Hr}_{1}$} & \multicolumn{1}{c}{$\mathrm{Hr}_{2}$} & \multicolumn{1}{c}{$\mathrm{Hr}_{3}$} & \multicolumn{1}{c}{$\mathrm{Hr}_{4}$} \\
\hline $\mathrm{SiO}_{2}$ & 0.030 & 0.040 & 0.010 & 0.040 \\
$\mathrm{TiO}_{2}$ & 0.010 & 0.010 & 0.090 & 0.040 \\
$\mathrm{Al}_{2} \mathrm{O}_{3}$ & 52.550 & 53.900 & 52.250 & 53.040 \\
$\mathrm{Cr}_{2} \mathrm{O}_{3}$ & 17.300 & 17.210 & 14.640 & 13.780 \\
$\mathrm{FeO}^{+}$ & 11.290 & 11.080 & 13.790 & 14.060 \\
$\mathrm{MnO}$ & 0.050 & 0.100 & 0.100 & 0.130 \\
$\mathrm{MgO}$ & 20.410 & 20.100 & 18.670 & 18.940 \\
$\mathrm{CaO}$ & 0.000 & 0.000 & 0.000 & 0.000 \\
$\mathrm{NiO}$ & 0.260 & 0.260 & 0.170 & 0.160 \\
$\mathrm{Sum}$ & 101.920 & 102.740 & 99.840 & 100.230 \\
$\mathrm{Si}$ & 0.001 & 0.001 & 0.004 & 0.006 \\
$\mathrm{Ti}$ & 0.001 & 0.001 & 0.003 & 0.001 \\
$\mathrm{Al}$ & 1.613 & 1.636 & 2.476 & 1.676 \\
$\mathrm{Cr}$ & 0.356 & 0.350 & 0.464 & 0.292 \\
$\mathrm{Fe}$ & 0.246 & 0.239 & 0.463 & 0.284 \\
$\mathrm{Mn}$ & 0.001 & 0.002 & 0.004 & 0.003 \\
$\mathrm{Mg}$ & 0.792 & 0.772 & 1.117 & 0.757 \\
$\mathrm{Ca}$ & 0.000 & 0.000 & 0.000 & 0.000 \\
$\mathrm{Ni}$ & 0.006 & 0.006 & 0.002 & 0.002 \\
\hline
\end{tabular}

Table 5: Electron microprobe analysis of phlogopite

\begin{tabular}{lrrrr}
\hline & \multicolumn{1}{c}{$\mathrm{Hr}_{1}$} & \multicolumn{1}{c}{$\mathrm{Hr}_{2}$} & \multicolumn{1}{c}{$\mathrm{Hr}_{3}$} & \multicolumn{1}{c}{$\mathrm{Hr}_{4}$} \\
\hline $\mathrm{SiO}_{2}$ & 38.69 & 39.42 & 38.33 & 37.44 \\
$\mathrm{TiO}_{2}$ & 6.82 & 6.52 & 6.37 & 7.06 \\
$\mathrm{Al}_{2} \mathrm{O}_{3}$ & 17.13 & 17.82 & 18.57 & 16.18 \\
$\mathrm{Cr}_{2} \mathrm{O}_{3}$ & 0.37 & 0.41 & 0.25 & 0.34 \\
$\mathrm{FeO}^{+}$ & 8.04 & 8.23 & 7.43 & 8.58 \\
$\mathrm{MgO}$ & 17.14 & 16.52 & 17.41 & 18.23 \\
$\mathrm{CaO}$ & 0.04 & 0.05 & 0.05 & 0.06 \\
$\mathrm{Na} 2$ & 2.11 & 2.14 & 2.15 & 2.31 \\
$\mathrm{~K}_{2} \mathrm{O}$ & 9.33 & 8.52 & 9.35 & 10.42 \\
$\mathrm{Sum}$ & 99.67 & 99.63 & 99.90 & 100.62 \\
& & & & \\
$\mathrm{Si}$ & 4.504 & 4.535 & 4.381 & 4.418 \\
$\mathrm{Ti}$ & 0.597 & 0.564 & 0.547 & 0.626 \\
$\mathrm{Al}$ & 2.351 & 2.416 & 2.502 & 2.251 \\
$\mathrm{Cr}$ & 0.034 & 0.037 & 0.034 & 0.032 \\
$\mathrm{Fe}$ & 0.782 & 0.791 & 0.710 & 0.847 \\
$\mathrm{Mg}$ & 2.973 & 2.832 & 2.965 & 3.206 \\
$\mathrm{Ca}$ & 0.005 & 0.006 & 0.006 & 0.008 \\
$\mathrm{Na}$ & 0.476 & 0.477 & 0.476 & 0.529 \\
$\mathrm{~K}$ & 1.385 & 1.251 & 1.362 & 1.569 \\
\hline
\end{tabular}

52.25-53.90 wt\%. The spinel is Fe-rich with $\mathrm{FeO}$ content ranging from 11.08-14.06 wt\%. They are also Cr-rich with $\mathrm{Cr}_{2} \mathrm{O}_{3}$ ranging between 13.78 and $17.30 \mathrm{wt} \%$. The $\mathrm{Cr} /(\mathrm{Cr}+\mathrm{Al})$ ratio match the $\mathrm{Cr}$-spinel given by ${ }^{[43]}$.

Phlogopite: Phlogopite form about 3-5 vol\% of the studied rocks. They dominating habitus is tabular and prismatic. They have a slight pleochroism from colorless to light yellow. They are characterized by one set of cleavage and have a parallel extinction. The phlogopite crystals are $0.2-5 \mathrm{~mm}$ in diameter. Phlogopites (Table 5) are moderately chromium-rich (0.25-0.41 wt\% $\quad \mathrm{Cr}_{2} \mathrm{O}_{3}$ ), sodium-rich (2.11-2.31 wt\% $\mathrm{Na}_{2} \mathrm{O}$ ), aluminum rich (16.18-18.57 wt\% $\left.\mathrm{Al}_{2} \mathrm{O}_{3}\right)$ and moderately titaniferous (6.52-7.06 wt\% TiO2). These phlogopites lie in the "secondary phlogopite" field associated with spinel peridotite ${ }^{[9]}$. 
Am. J. Applied Sci., 6 (12): 2085-2092, 2009

Table 6: Whole rock chemical analyses of spinel lherzolite xenoliths from Jabal Al-Harida.

\begin{tabular}{|c|c|c|c|c|}
\hline & $\mathrm{Hr} 1$ & $\mathrm{Hr} 2$ & $\mathrm{Hr} 3$ & $\mathrm{Hr} 4$ \\
\hline \multicolumn{5}{|c|}{ Major oxides } \\
\hline $\mathrm{SiO}_{2}$ & 44.17 & 43.14 & 42.31 & 42.48 \\
\hline $\mathrm{TiO}_{2}$ & 0.22 & 0.15 & 0.10 & 0.21 \\
\hline $\mathrm{Al}_{2} \mathrm{O}_{3}$ & 1.53 & 1.54 & 1.79 & 1.44 \\
\hline $\mathrm{FeO}^{\mathrm{t}}$ & 8.01 & 8.18 & 8.86 & 9.24 \\
\hline $\mathrm{MnO}$ & 0.11 & 0.11 & 0.12 & 0.12 \\
\hline $\mathrm{MgO}$ & 43.11 & 44.23 & 44.28 & 44.13 \\
\hline $\mathrm{CaO}$ & 1.86 & 1.42 & 1.78 & 1.63 \\
\hline $\mathrm{Na}_{2} \mathrm{O}$ & 0.13 & 0.23 & 0.13 & 0.17 \\
\hline $\mathrm{K}_{2} \mathrm{O}$ & 0.03 & 0.05 & 0.04 & 0.04 \\
\hline $\mathrm{P}_{2} \mathrm{O}_{5}$ & 0.04 & 0.04 & 0.02 & 0.05 \\
\hline LOI & 0.63 & 0.35 & 0.49 & 0.73 \\
\hline Sum & 99.84 & 99.44 & 99.92 & 100.07 \\
\hline \multicolumn{5}{|c|}{ Trace elements (ppm) } \\
\hline $\mathrm{Sc}$ & 8.00 & 7.00 & 8.00 & 9.00 \\
\hline V & 62.00 & 39.00 & 41.00 & 52.00 \\
\hline $\mathrm{Rb}$ & 13.00 & 15.00 & 15.00 & 17.00 \\
\hline $\mathrm{Ba}$ & 32.00 & 22.00 & 26.00 & 31.00 \\
\hline Co & 120.00 & 117.00 & 121.00 & 132.00 \\
\hline $\mathrm{Cr}$ & 2619.00 & 2631.00 & 2563.00 & 2552.00 \\
\hline $\mathrm{Ni}$ & 2891.00 & 2731.00 & 2288.00 & 2214.00 \\
\hline $\mathrm{Y}$ & 6.00 & 6.00 & 7.00 & 8.00 \\
\hline $\mathrm{Sr}$ & 32.00 & 27.00 & 32.00 & 35.00 \\
\hline $\mathrm{Zn}$ & 80.00 & 62.00 & 54.00 & 60.00 \\
\hline $\mathrm{Zr}$ & 18.00 & 16.00 & 17.00 & 19.00 \\
\hline
\end{tabular}

Opaque minerals: Opaque minerals (1-3\%) are mainly euhedral to subhedral in shape. Most of them are magnetite grains. Their petrographical characteristics show that they are of the chromium type.

Bulk geochemistry: Bulk chemistry of four representative samples show that the xenoliths have comparable amounts of major oxides (Table 6). They have a low silica content that ranges from 42.31-44.17 $\mathrm{wt} \%$ allowing them to be classified as ultramafic rather than mafic. They are characterized by high $\mathrm{MgO}, \mathrm{Cr}, \mathrm{Ni}$ content and relatively low contents of $\mathrm{Al}_{2} \mathrm{O}_{3}, \mathrm{FeO}, \mathrm{CaO}$ and $\mathrm{K}_{2} \mathrm{O}$. However, their range of chemical composition is similar to the average of lherzolite of upper mantle origin reported by ${ }^{[44]}$.

\section{CONCLUSION}

The petrographical characteristics, textures and chemistry of the studied xenoliths suggest that they are pieces of upper mantle material brought up by the host magma during the ascent (Fig. 3). The xenoliths of the Jabal Al-Harida volcano have a mineralogical composition similar to the other occurrences in Jordan $^{[45,27]}$ and in Saudi Arabia ${ }^{[20,46]}$.

Thermometry estimation of the Jabal Al-Harida xenoliths are calculated by using a BASIC computer program based on the two-pyroxene method of ${ }^{[47]}$ and was applied to co-existing pyroxenes and tested against experimental data on the delegate xenoliths ${ }^{[46]}$.



Fig. 3: Schematic diagram of mantle and crust under the Jabal Al-Harida Volcano, Jordan. Data of partial melting zone depth of the host magma are obtained from Al-Malabeh ${ }^{[29]}$

For Jabal Al-Harida xenoliths, the Herzberg method gave temperatures ranging from $960-1040^{\circ} \mathrm{C}$. Barometry estimates for spinel lherzolite are inherently difficult, since no accurate barometer exists for spinel bearing xenoliths. Approximate minimum and maximum pressure equilibration estimates are obtained from the observed mineral assemblage, particularly from the presence or absence of spinel or garnet and by looking at the mole fraction of $\mathrm{Cr}_{2} \mathrm{O}_{3}$ in the spinel ${ }^{[48]}$ and correlate it to CMAS $\left(\mathrm{CaO}-\mathrm{MgO}-\mathrm{Al}_{2} \mathrm{O}_{3}-\mathrm{SiO}_{2}\right)^{[49]}$. The pressure estimate of the studied samples yields ranges between 11-13 $\mathrm{Kb}$. The estimated values compare well with estimates for spinel lherzolite xenoliths $12-15 \mathrm{~Kb}, 925-1025^{\circ} \mathrm{C}^{[39]}, 12-18 \mathrm{~Kb}^{[50]}$ and $13-19 \mathrm{~Kb}$ and $990-1070^{\circ} \mathrm{C}^{[27]}$. However, the depth of the host magma must exceed the source of the highestpressure xenoliths (Fig. 3).

The presence of phlogopite in the studied xenoliths makes an argument and represents convincing evidence for a metasomatism in the mantle at the depth where the xenoliths were extracted ${ }^{[50]}$. It reflects a modal evidence for the replacement of primary minerals by hydrous minerals and is indicative of metasomatism. Phlogopite is stable at temperatures of $900-1300^{\circ} \mathrm{C}^{[51]}$ and indicates the presence of water in the upper mantle. However, metasomatism is a mechanism for promoting chemical change in the upper mantle in a solid-state transformation without melting ${ }^{[50]}$. The most metasomatizing fugitive constituents are $\mathrm{H}_{2} \mathrm{O}, \mathrm{CO}_{2}$ among other fluids. The limited occurrence of 
metasomatized minerals (hydrous minerals compared with the volume of MARID minerals. (micaamphibole-rutile-ilmenite-diopside) are similat to xenotliths associated with kimberlites ${ }^{[52]}$. This may reflect that the metasomatism degree in Jabal Al-Harida was not high. The slight selective enrichments of some incompatible elements such as $\mathrm{Sr}, \mathrm{Rb}$ and $\mathrm{Ba}$ may be due to cryptic metasomatism as defined by ${ }^{[9]}$ and coincides with the latter results.

\section{ACKNOWLEDGMENT}

The researcher is deeply grateful to the technical staff in the Department of Mineralogy, Würzburg University for their XRF analyses and the University of Tübingen Germany for their help in SEM analyses. Also, the author is highly indebted to Prof. Dr. S. Kempe of Darmstadt University, Germany for his critical review of the manuscript.

\section{REFERENCES}

1. Lloyed, F., 1987. Characterization of Mantle Metasomatic Fluids in Spinel Lherzolites and Alkali Clinopyroxenites from the West Eifel and South Uganda. In: Mantle Metasomatism, Menzies and Hawkesworth (Ed.). Academic Press, pp: 91-123.

2. Downes, H., 1980. Relationship Between Geochemistry and Textural Type in Spinel Lherzolites, Massif Central and Languedoc, France. In: Mantle Xenoliths, Nixon, P.H. (Ed.). John Wiley and Sons Ltd., pp: 125-133.

3. Lloyed, F. and D. Bailey, 1975. Light element metasomatism of the continental mantle: The evidence and the consequences. Phys. Chem. Earth, 9: 389-416. http://adsabs.harvard.edu/abs/1975PCE....9..389L

4. Roden, M., F. Frey and D. Francis, 1984. An example of consequent mantle metasomatism in peridotite inclusions from nunival Island. Alaska J. Petrol., 25: 546-577.

5. Bailey, D., 1982. Mantle metasomatismcontinuing chemical change within the earth. Nature, 296: 525-530. http://adsabs.harvard.edu/abs/1982Natur.296..525B

6. Ionov, D., J.L. Bodinier, S. Mukasa and A. Zanetti, 2002. Mechanisms and sources of mantle metasomatism: Major and trace element compositions of peridotite xenoliths from spitsbergen in the context of numerical modeling. J. $\quad$ Petrol., 23: 219-2259. http://petrology.oxfordjournals.org/cgi/content/abst $\mathrm{ract} / 43 / 12 / 2219$
7. Bonadiman, C., M. Coltorti, L. Beccaluva and F. Siena, 2008. Mantle metasomatism VS host magma interaction: The ongoing controversy. EGU general assembly. Geophys. Res. Abstr., 10.

8. Holmes, A., 1965. Principles of Physical Geology. 2nd Edn., London and Edinburgh, pp: 730.

9. Erlank, A., F. Waters, C. Hawkesworth, H. Haggerty and H. Allsopp 1987. Evidence for Mantle Metasomatism in Peridotite Nodules from the Kimberley Pipes. In: Mantle Metasomatism, Menzies and Hawkesworth (Ed.). Academic Press, South Africa, pp: 221-311.

10. Harte, B., 1987. Metasomatic Events Recorded in Mantle Xenoliths: An Overview. In: Mantle Xenoliths, Nixon, P.H. (Ed.). Wiley and Sons, USA., pp: 625 - 640.

11. Eggler, D., 1987. Solubility of Major and Trace Elements in Mantle Metasomatic Fluids: Experimental Constraints. In: Mantle Metasomatism, Menzies and Hawkesworth (Ed.). Academic Press, pp: 21-41.

12. Roedder, E., 1965. Liquid $\mathrm{CO}_{2}$ inclusions in olivine-bearing nodules and phenocrysts frombasalts. Am. Minerat, 50: 1746-1782.

13. Murk, B.W., R.C. Burruss and L.S. Hollister, 1978. Phase equilibria in fluid inclusions in ultramafic xenoliths. Am. Mineral., 63: 40-46. http://ammin.geoscienceworld.org/cgi/content/abstr act $/ 63 / 1-2 / 40$

14. Bergman, S.C. and J. Dubessy, 1984. $\mathrm{CO}_{2}-\mathrm{CO}$ Fluid inclusions in a composite peridotite xenolith: Implications for upper mantle oxygen fugacity. Contrib. Mineral. Petrol., 85: 1-13. http://adsabs.harvard.edu/abs/1984CoMP...85...1B

15. Rickwood, P. and M. Mathias, 1970. Diamondiferous eclogite xenoliths in kimberlite. Lithos, 3: 223-235. DOI: 10.1016/00244937(70)90075-7

16. Wells, P., 1977. Pyroxene thermometry in simple and complex systems. Contrib Mineral. Petrol., 62: 129-139.

17. Kornprobst, J., 1984. Kimberlites II: The Mantle and Crust-Mantle Relations. Elsevier, Amsterdam, pp: 393.

18. Al-Malabeh, A. and K. Ibrahim, 2001. Discovery of meter-sized ultramafic xenoliths in Jabal Ashqaf volcano. Proceeding of the 5th Conference on Geochem, Abstracts Band, (CBA'01), Alexandria, Egypt, pp: 20-21.

19. De Vivo, B., M. Frezzotti, A. Lima and R. Trigila, 1988. Spinel lherzolite nodules from Oahu island (Hawaii): A fluid inclusion study. Bull. Mineral., 111: 307-319. 
20. McGuire, A., 1988. The mantle beneath the red sea margin: Xenoliths from western Saudi Arabia. Tectonophysics, 150: 101-119. http://adsabs.harvard.edu/abs/1988Tectp.150..101M

21. Baker, P., R. Brossel, I. Gass and C. Neary, 1973. Jebel al abyad: A recent alkali volcanic complex in western Saudi Arabia. Lithos, 6: 291-314.

22. Ghent. E.D., R.G. Coleman and D.G. Hadley, 1980. Ultramafic inclusions and host alkali olivine basalts of the southern coastal plain of the red sea, Saudi Arabia. Am. J. Sci., 280-A: 499-527. http://earth.geology.yale.edu/ ajs/1980/ajs_280A_ 1.pdf/499.pdf

23. El-Sharkawi, M.A., 1982. Lherzolite xenoliths from the shihan basalts, Jordan. Science, 9: 286-299.

24. Al-Malabeh, A., 1989. The volcanic successions of jebal aritain volcano, NE-Jordan: A field, petrographic and geochemical study. M.Sc. Thesis, Yarmouk University, Jordan, pp: 182.

25. Fakhoury, I., 1991. Mineralogy, phase-petrology and geochemistry of mafic and ultramafic xenoliths in the Quaternary basalts, NE-Jordan. Unpubl. M.Sc. Thesis, Yarmouk University, Jordan, pp: 155.

26. Blusztain, J., S. Harte, N. Shimizu and A. McGuire, 1995. Trace-element and isotopic characteristics of spinal peridotite xenoliths from Saudi Arabia. Chem. Geol., 123: 53-65.

27. Nasir, S. and A. Safarjalani, 2000. Lithospheric petrology beneath the northern part of the Arabian plate in Syria: Evidence from xenoliths in alkali basalts. J. African Earth Sci., 30: 149-168. DOI: 10.1016/S0899-5362(00)00013-0

28. Shaw, J.E., J.A. Baker, A.J.R. Kent, K.M. Ibrahim and M.A. Menzies, 2007. The geochemistry of the Arabian lithospheric mantle-a source for intraplate volcanism? J. Petrol., 48: 1495-1512. http://petrology.oxfordjournals.org/cgi/content/abst ract/48/8/1495

29. Al-Malabeh, A., 1994. Geochemistry of two volcanic cones from the intra-continental plateau basalt of Harra El-Jabban, NE-Jordan. Geochem. J. Jap., 28: 518-540.

30. Al-Malabeh, A., 2005. New discoveries supporting eco-tourism in Jordan. 1st Economic Jordanian Forum. Abstracts, pp: 6.

31. Al-Malabeh, A., 2003. Geochemistry and volcanology of jabal al-rufiyat, strombolian monogenic volcano, Jordan. Dirasat, 30: 125-140.

32. Al-Malabeh, A., 1993. The volcanolgy, mineralogy and geochemistry of selected pyroclastic cones, from ne-Jordan and their evaluation for possible industrial applications. Ph.D. Thesis, Eragen University, Germany, pp: 300.
33. Cas, R. and J. Wright, 1987. Volcanic Successions, Modern and Ancient. Allen and Unwin, London, pp: 528.

34. Mercier, J. and A. Nicolas, 1975. Textures and fabrics of upper mantle peridotites as illustrated by xenoliths from basalts. J. Petrol., 16: 454-487. http://petrology.oxfordjournals.org/cgi/content/abst $\mathrm{ract} / 16 / 2 / 454$

35. Frey, F. and M. Prinz, 1978. Ultramafic inclusions from San C, Arizona, petrogenesis and geochemical data bearing on their petrogeneises. Earth Planet. Sci. Lett., 38: 129-176.

36. Wilshire, H. and J. Shervais, 1975. Al-augite and cr-diopside ultramafic xenoliths in basaltic rocks from western united states. Phys. Chem. Earth, 9: 257-272.

37. Wedephol, K., 1975. Contribution of chemical data to assumption about the origin of magmas from the mantle. Forschr. Mineral., 52: 141-172.

38. Sato, H., F. Tchoua and M. Kusakabe, 1991. Olivine phenocrysts in some cameroonian basaltimplications for primary magmas composition. Mineral. $\quad$ Petrol., 44: 253-269. http://adsabs.harvard.edu/abs/1991MinPe..44..253S

39. Nasir, S. and H. Al-Fugha, 1988. Spinel lherzolite xenoliths from the Aritain volcano, NE-Jordan. Mineral. Petrol., 39: 127-137. DOI: 10.1007/BF01164317

40. Morimoto, N., J. Fabbies, A. Ferguson, I. Ginzburg and M. Ross et al., 1988. Nomenclature of pyroxenes. Mineral. Petrol., 39: 55-76.

41. Deer, W., R. Howie and J. Zussman, 1962. RockForming minerals. John Wiley and Son, Oxford, pp: 333.

42. Al-Malabeh, A., 2004. Discovery of ultramafic xenolith-rich layer in the tephra successions of Jabal Aritain-South, Jordan. R.J. Mineral. Deposits, 12: 23-35.

43. Carswell, D., 1980. Mantle derived lherzolite nodules associated with kimberlite, carbonatite and basalt magmatism: A review. Lithos., 13: 121-138. http://adsabs.harvard.edu/abs/1980Litho..13..121C

44. Thompson, R., 1986. Sources of basic magmas. Nature, 319: 448-449.

45. Hafez, A., 1986. Upper mantle-derived ultramafic xenoliths from Jebel Aritain, Hashemite Kingdom of Jordan. Ann. Geol. Surv. Egypt, 15: 129-136.

46. Kuo, L.C. and E. Essene, 1986. Petrology of spinel harzburgite xenoliths from the Kishb plateau, Saudi Arabia. Contrib. Mineral. Petrol., 93: 335-346. DOI: $10.1007 / \mathrm{BF} 00389392$ 
47. Herzberg, C., 1978. Pyroxene geothermometry and geobarmometry: Experimental and thermodynamic evolution of some subsolidus phase relations involving pyroxenes in the system $\mathrm{CaO}-\mathrm{MgO}-$ $\mathrm{Al}_{2} \mathrm{O}_{3}-\mathrm{SiO}_{2}$. Cosmochim. Acta, 42: 945-957.

48. Irving, A., 1974. Geochemical and high pressure experimental studies of garnet pyroxenite and pyroxene granulite xenoliths from the delegate basaltic pipes, Aust. J. Petrol., 15: 1-40. http://petrology.oxfordjournals.org/cgi/content/abst ract/15/1/1

49. O'Neill, H., 1981. The transition between spinel lherzolite and garnet lherzolite and its use as a geobarometer. Contrib. Mineral. Petrol., 77: 185-194. DOI: $10.1007 / \mathrm{BF} 00636522$

50. Princivalle, F., M. Tirone and P. Comin-Chairamonti, 2000. Clinopyrxenes from metasomatized spinelperidotite mantle xenoliths from Nemby (Paraguay): Crystal chemistry and petrological implications. Mineral. Petrol., 70: 25-35.
51. Neal, C. and L. Taylor, 1989. The petrography and composition of phlogopite micas from the Blue Ball kimberlite, Arkansas: A record of chemical evolution during crystallization. Mineral. Petrol., 40: 207-224. DOI: $10.1007 / \mathrm{s} 004100000151$

52. Dawson, J. and J. Smith, 1977. The MARID (mica-amohibole-rutile-ilmenite-diopside) suite xenoliths in kimberlite. Geochim. Cosmochim Acta, 41: 309-310. http://adsabs.harvard.edu/abs/1977GeCoA..41..309 $\mathrm{D}$ 